Acta regionalia et environmentalica 1

Nitra, Slovaca Universitas Agriculturae Nitriae, 2014, p. 24-29

\title{
THE PROBLEMS OF KNOWLEDGE ECONOMY AND INNOVATION PROCESSES IN AGRICULTURE Case Study of the Nitra Region
}

\author{
Mária FÁZIKOVÁ*, Katarína MELICHOVÁ \\ Slovak University of Agriculture in Nitra, Slovak Republic
}

\begin{abstract}
Agriculture is an important element of rural economy development, currently facing many problems. The unfinished process of economic transformation, division of land use and land ownership, disintegrated social networks, under-developed institutions these are the problems hindering the knowledge economy enforcement. Among the agricultural enterprises there is a high level of distrust resulting into low cooperation, reluctance against partnerships and networks which represent the main instrument for knowledge economy enforcement. Moreover, the current EU agricultural policy which is adjusted for agricultural conditions in the old member states hampers innovation activities of agricultural enterprises and conserves inefficient structures in them.
\end{abstract}

Keywords: agriculture, rural areas, knowledge economy, innovations, agricultural policy

Agriculture is one of the industries where a system approach to innovation has been for several reasons least applied. Institutional barriers and the'distance' between research and practice meant that, in many countries, farmers' knowledge has only insufficiently been taken into consideration as a possible source of innovation (Scoones and Thompson, 2009). The support frameworks that predominanted before the reforms of the Common Agricultural Policy during the past 15 years had encouraged a pattern of innovation and innovation systems thad focused above all on an efficient production of primary agricultural commodities and on commercial inputs subject to patent laws; all this was guided primarily by economic consideration and a particular image of a 'modern' agricultural sector (Knickel Tisenkopfs and Peter, 2009). Nowadays in agri-food sector started a new phase of restructuring and concentration caused by the globalization process. As McMichael (2004) states, "...closed commodity chains are rapidly being replaced by wholesale or immediate markets. They are ruled by non-agricultural sectors which take advantage of global purchasing and use the advantages of processing and transport technologies". Existing forms of direct control of the agricultural production are being replaced by new forms of "remote control" through standards determined by the trade (Pimbert et al., 2010). Discussion about the agricultural model suggests that agricultural systems switch from "productivist era" to "post-productivist era" (Wilson and Rigg, 2004). Ploeg et al. (2000) posit that a new model of development of agriculture and rural areas starts to appear. Modernization paradigm is being replaced by a new rural development paradigm. In agri-food system, it means shift towards the quality, and linking to new alternative agrofood chains (Godin, 2010). After a period of innovations of the first level, the onset of innovations of second level follows - radical innovations (Brunori et al., 2010). In a new model of "multifunctional agriculture" being enforced, the innovations of second level appear, based on the "non- linear model" based on the social capital. Innovations arise from within the changing production networks in this case (Burt, 2004). Innovations in agriculture are demand-driven. A key challenge to agricultural innovations is to find out a new ways in the processing, marketing and value adding capacity of agriculture as well as the exploration of new opportunities in new rural and environmental services and non-food production (Knickel, Tisenkopfs and Peter, 2009). The creation of such innovations rises from the changing interactions between the actors, instruments and natural resources (Ploeg et al., 2004).

\section{Material and methods}

The objective of the paper is to explore the dynamics of knowledge-based processes in agricultural enterprises in rural regions in Slovakia. The Nitra Region was chosen as a representative of the regions.

The most productive land in Slovak Republic with the highest value in the context of land consolidation is located in the Nitra region. The average production potential of agricultural land is 68.6 points, while the average for Slovakia is 44.4 points. High production potential of agriculture in the Nitra region classifies it as a strategic sector, considering one third of the country's agricultural production is produced here $(36 \%$ of total production of grain an $32 \%$ of total production of oil seeds in Slovakia). This region also has the highest employment rate in agriculture relative to other regions in Slovakia (6.2\%), as well as the highest average size of agricultural enterprises. However, this situation generates development problems in the region. Agriculture is a sector that is characterized by low production of value added. The share of value added increases during processing of agricultural raw materials. The paradox of the Nitra region is that despite the high agricultural production, there is low processing capacity, reducing the region's potential 
for value added growth. Regional market for agricultural products is non-existent; agricultural enterprises are linked to the national and global markets. They are thus exposed to enormous competitive pressure, which they confront differently. Pressure of global markets on lowering prices of agricultural raw materials compels agricultural enterprises to implement mainly technological and process innovation, enabling them to increase labour productivity. Constantly growing price gap between rising prices of agricultural inputs and stagnating or decreasing product prices induces diminution of profits of agricultural enterprises and thus their value added. This forces them to reduce input costs i.e. reach for new production possibilities. Their competitiveness, based on an ability of flexible reactions towards the changing cognitive frameworks and sociotechnical systems, is a key one for the region as well as for Slovak economy.

The methodical approach was based on the secondary and primary research. The secondary research was aimed at provision of the basic framework for searching on dynamics of knowledge trajectories. Within the research, existing statistical sources (Statistical Office of the Slovak Republic, EUROSTAT, Farm Accountancy Data Network), Reports on Agriculture and Food Industry of the Slovak Republic (green report), available research papers, conceptual and strategic documents (Prognosis and vision of development of Slovak agriculture, food industry, forestry and rural areas; Rural Development Programme 2007-2013), EU studies and documents and others were analysed. Next, the primary research was focused on the analysis of the dynamics and knowledge trajectories in creation of innovations in agricultural enterprises within the Nitra region - the representative of Slovak rural regions. As a methodical tool for acquirement of primary data we used a structured interview.

The structure of interview questions was based on a research assumption (formulated on the basis of knowledge gained via study of relevant literature) formulated as follows: "Knowledge creation is seen as a collective process that requires mobilization of more agents. This process is significantly influenced by economic, territorial, social and policy factors".

This assumption was verified using basic and additional questions that were sorted according to the factors influencing the process of knowledge creation in the sector.

Questions identifying factors of knowledge creation:

- Which type of knowledge (internal or external?) is critical?

- Is the dynamics of knowledge in the sector characterized by cumulative or composite processes?

- Do the processes of specialization or the processes of diversification prevail in the sector?

- What is the role of substantial financial sources in the processes of knowledge creation, acquiring and distribution? What is the role of policy in changes within the sector and the region?

- Which policy instruments influence the condition of the sector and the enterprise the most?

All of the basic questions were supplemented by additional questions which specified individual problem areas in detail.
The choice of the interviewed enterprises and managers was performed under the following criteria: the managers should have represented socially accepted experts, the enterprises should have represented the most important legal forms of agricultural enterprises (agricultural cooperatives, commercial companies, individual farmers) and also the level of their specialization were taken into account. The total of 16 managers took part in the structured interview; seven of them represented traditional agricultural businesses, six of them represented partly specialized and specialized ones.

\section{Results and discussion}

The period of transformation towards the conditions of functioning market economy affected agriculture more than the other sectors (Bandlerová, 2005). The transformation process in agriculture is more or less still unfinished (Blažík et al., 2011). This fact was percepted by the respondent managers as not a suitable transformation model. The general attitude of the participating managers to the actual results of the transformation process in agriculture is described in the following quotations: "...the direct responsibility for long-term results of the company is not up on managers' shoulders. The management of the company is divided from ownership of factors of production. The transformation model should have been based on the specialization of smaller farms where there is a direct responsibility of an owner. People (owners, professional employers) did not want to go into the conflict which had been brought about by transformation, a good level of agricultural companies connected with ownership and successful land use and high yield was not created. The previous ownership structure still determines the current one and limits the development of economically effective forms of land use".

\section{Which type of knowledge (internal or external) is critical?}

The change in economic system and access of Slovakia to the European Union brought to the farmers not only transformation problems in field of ownership relations but also an opportunity for technical and technological innovation and growth in labour productivity. The technological level in agriculture increased substantially due to free access to the newest technologies. This was reflected mainly in growth of labour productivity in agriculture (Koncoš 2006). Although the respondents recognize that the market opening contributed to technical and technological restructuring of agricultural production base and to a marked increase in a labour productivity, the respondents expressed themselves as follows: "Technological level has increased and there was also an opportunity to buy new machines, the access to food market has loosened, ICTs speed up information'"'Technological level has increased, modern technologies, agrochemicals and quality seed corns were made available".

Agricultural sector in the Slovak Republic is in the process of technological rebuilding. In the current development phase, technological innovations are pivotal 
for the agriculture. Sources of technological innovations are external and due to the fact that there are few producers of technological innovations in Slovakia a large part originates on global markets.

\section{Is the dynamics of knowledge in the sector} characterized by cumulative or composite processes?

Stage of technological innovation in Slovak agriculture is approaching its apex. Gradually, successful examples of managerial and marketing innovations are emerging (Fáziková et al., 2011), their sources derivable mainly from internal knowledge of managers. Transforming a new idea into innovation is a process that requires knowledge in fields other than agriculture. The introduction of innovations, new products and services requires specialists from other sectors beside agriculture. Agricultural enterprises acquire these specialists by training their own employees or employing new ones with relevant qualifications. One respondent stated that,$\ldots . .$. every new product requires a comprehensive self-study on the manager's part, but also employment of specialists. For example, the start of a feed compound production required the launch of agro-laboratory which resulted in hiring a specialist".

The innovation processes in agricultural enterprises result mostly in technological improvements. Examples of managerial innovations in the form of more effective production factors combination also emerge. Agricultural enterprises extend their market share by expanding to markets of other sectors, especially in services for agriculture (production of compound feed, insemination of animals) energy sector (biogas production), timber processing (sawmilling) in the field of tourism but also in specific sectors such as exotic birds breeding. Also, agricultural enterprises see improvement of their position in shortening the supply chain and gaining of larger share of the profit margin (through direct sale of products to the end consumer).

Therefore, in today's agriculture a cumulative processes aimed at improving the level of knowledge are apparent, but there are also composite processes manifested in an effort of agricultural enterprises to penetrate markets of other sectors.

\section{Do the processes of specialization or the processes of diversification prevail in the sector?}

Opening to global markets has brought new impetus for agricultural enterprises. In the initial period they were being subjected to enormous pressure in establishing new business contacts. However, the situation is stabilizing and agricultural enterprises are adapting in their structure to the new market requirements. Attitudes of respondents can be illustrated by the following statement of one respondent: "The current structure of production in agricultural enterprises is affected by the past economic structure of the region to a very small extent. Most of the processors located in the region ceased to exist (brewery, meat processing industry, dairy industry, mill). The sales centres shifted away significantly. This resulted in a phenomenon of predominant cereals export" Global markets with agricultural products are widely volatile, forcing agricultural enterprises to look for opportunities to raise revenue in other ways aside from the sale of agricultural raw materials. Agricultural enterprises included in the survey sample employ various forms of diversification, resulting in particular from opportunities in relation to local resources. For example: processing of agricultural crops for feed compounds for their own use as well as for sale, agrochemical analysis of soil and raw materials for their own use and for others, haulage services, carpentry, locksmith and repair services, construction work, but also consultancy in preparing applications for grants from rural development program.

Technical and technological development and the situation on the global markets are pushing agricultural enterprises to narrow specialization. Agricultural enterprises generally specialize in production of 2-3 kinds of crops (cereals, oilseeds, fodder crops on arable land), but a tendency to diversify is apparent, particularly in technologically forward enterprises, that are establishing their position with developed technologies and implicit know-how, particularly on regional services market.

\section{What is the role of substantial financial sources in the processes of knowledge creation, acquiring and distribution?}

Funding is an important factor in the process of introducing innovations in agricultural enterprises. Fáziková and Mariš (2010) state that for all agricultural enterprises, regardless of their size and financial strength, the high cost of generating their own innovations and lack of funds for acquiring innovation from external sources are the most important barriers to innovation processes. Businesses compare the quality of innovation input and price, while quality is a major factor. Businesses spend $10-20 \%$ of their investment budget on innovation. The willingness of firms to finance generation of their own innovations is small, which stems from the high cost and high risk of innovating, as well as non-financial factors (lack of skilled labour, lack of cooperative partners among companies, the complexity of the institutional environment). Important source of innovation financing are subsidies.

Financial resources play a key role in the innovation process of agricultural enterprises. The most important is the financial stability of the business, which gives them the necessary impetus for decisions on innovation.

\section{Which policy instruments influence the condition of the sector and the company the most?}

As of the accession of the Slovak Republic to the EU, Slovak agriculture utilizes the tools of the Common Agricultural Policy, respects its principles and applies its instruments. The subvention support in the EU is very high. The importance of an institutional support for innovations is inevitable for agricultural enterprises. Most of respondents said that without the institutional support there would probably be no innovations. Resources to support innovation in agriculture are available in the second pillar of the CAP, which is aimed at rural development. The aid system functions on a grant platform, subventions are therefore selective.

The selectness of such support because of limited budgetary sources remains an unsolved problem in agriculture. Innovations are therefore supported selectively; 
their diffusion is not of a continuous character but rather of a random one (Fáziková et al., 2011). This information is fully approved by results achieved from in-depth interviews with chosen agricultural managers. All of them perceive the innovation policy of the state negatively. According to them, "...there is no substantial support."."...active support for new technologies introduction is absent, there is a need for a change in an approach towards agriculture, for a support towards orientation on nutrition and quality of food." "Focus on investment supports does not force enterprises towards a maximal economic efficiency. State should support compensation of interests within investment loans. There is a trend of corrupt practices in decision-making concerning the subsidies." "Some branches, such as poultry breeding, small animals breeding, growing vegetables were pushed to the periphery of policy interests."'...the support for export and publicity and soft loans are absent."

The managers took a particularly critical stand towards an agricultural policy of the Slovak Republic. They are not satisfied with a total amount of subsidies as they are disadvantaged compared to the farmers from the old member states. The share of subsidies on a total amount of production of the agricultural enterprises (PSA) is $36 \%$ in the EU, whereas in Slovakia it is only 20 \% (Fáziková and Mariš, 2010). This fact is perceived by the farmers as a clear discrimination on the part of the state and the EU, creation of a competitive disadvantage, attenuation of investment development and labour productivity growth.

The managers also feel insufficient conceptual, political and financial support for agriculture. "The state defined a role of agriculture and rural areas. Yet there is no accepted relevant conception. Chaos and disunity persist. Slovakia wastes billions compared to the old member states". The managers sense an inability of state to identify future developmental trends in agriculture and, based on it, to appoint a conception, supported by relevant economic and managerial instruments. One of the managers expressed the following opinion, representing the view of the majority of respondents: "...an unclear conception of agricultural transformation caused destruction of many systems, e.g. destruction of high school and vocational education."

The managers see the role of policy in transformation of the region and, particularly, of the agricultural sector very differently. Their opinions and attitudes can be divided into two groups. The first one is represented by managers of agricultural enterprises with traditional structure of production; they see the role of policy as an important one, but rather with a negative and discriminating light. "The role of policy is a cardinal one. The governments try to damp agriculture by reduction of subsidies." "It was a crucial political mistake that the primary producers were disabled to privatize the processing industry and it caused a destruction of supplier - purchaser relationships and, thus, destruction of regional food markets." "The instruments of the EU agricultural policy have a low efficiency." "The positive effect of the Common Agricultural Policy is an opportunity to buy new technologies from the Rural Development Programme."

The second group is formed by the specialized enterprises managers, farming on smaller areas in general, using the agricultural subsidies only in a limited scope. Thus, they face the effects of global competition. The EU Agricultural Policy does not influence them considerably. However, they consider the accession to the EU and subsequent opportunities rather positively. According to them: “...policy had an important effect on enabling the entrepreneurship, loosening export and import.", "Transition from centrally planned production to a free market enabled to establish the success of companies on abilities of managers."

Among the policy instruments being implemented to promote innovation in agriculture, the most important (in Slovakia, the only ones so far) are the instruments of rural development policy. Agricultural enterprises successful in acquiring these grants have advanced to the technological top in Slovakia, but also in Europe. However, access to these resources is selective; therefore, the problems of lagging innovation processes in Slovak agriculture are not resolved systemically.

\section{Conclusion}

The results of the paper indicate several problems in the innovation processes in the Slovak agriculture. Mainly immaturity of the industry in terms of innovation, as in the implementation of innovation in the sector, an important role is played by the managers of the enterprises who have a specific vision of the future position of the enterprises. They are able to identify and take advantage of new opportunities, work on their key competencies and are internally motivated. Knickel et al. (2009) argues that in the emergence phase of innovation in agriculture the role of initiatiors is crucial. The 'I' motivation prevails. Innovators are often left alone. At the emergence they focus on the 'I' process and not on the content of available potential support. Innovations emerge in certain context, so the market potential and their social acceptance is essential. Nevertheless, the managers are often the only bearers of innovative thoughts due to the immaturity of external and internal environment, low density of institutions, disintegrated social networks, and absence of regional innovative systems and underdevelopment of in-plant innovative and incentive systems. The other co-workers are often in position of executors, waiting for direct orders. This causes a high fragmentation of economic activities connected with diffusion, absorption and utilization of knowledge which run within the small circle of agents without coordination.

The second set of issues is related to the immaturity of the agricultural sector in Slovakia. This immaturity is rooted in a pending transformation of agricultural enterprises, as well as the desintegration of the agri-food sector. Value chain of agriculture is highly globalized. Sectors based on the inputs as well as the outputs of the agricultural production process are largely located abroad. For primary agricultural producers this means restricted access to markets of production factors and sales markets. Structure of production in agricultural enterprises is not profiled, resulting in instability of the sector. Constantly on-going contradictory processes of specialization and diversification put different demands on the types of knowledge and innovation. 
The third set of issues stems from the agricultural policy being implemented. The political dimension of enforcement of knowledge economy and innovations in agriculture is within the framework of the EU Common Agricultural Policy. Regarding the uneven position of the enterprises within the food production vertical, the effects reached by technological innovations manifest in a labour productivity growth and reduction in costs per unit; however, they do not manifest adequately in increased profitability and, thus, in competitiveness of agricultural enterprises. Therefore, such agricultural policy is little efficient because its effects overfall into processing sector and into profits of business chains. The support for product innovations realized through measures focused on diversification of agricultural enterprises towards non-agricultural activities seems to be a more efficient, pro-innovative policy. However, only a small part of the total subsidy sources was directed to this policy; that is why the potential of product innovations could not have been realised so far. Although there is a great volume of financial support which flows into agricultural enterprises through the CAP, the enterprises feel its insufficient coordination, internal inconsistency and weak efficiency of its tools in field of innovations.

In conclusion, we can state that the sector of agriculture is still undergoing economic transformation and its transition towards knowledge economy has been rather spontaneous than systematic. Despite the productivity growth achieved through technology innovations, Slovak agriculture is less competitive in comparison with developed European agriculture. Managerial innovation and innovation in marketing of agricultural products are rather rare. Unsystematic and fragmented approach to innovation in most segments of the value chain (research, production, processing, sales) is manifested in the declining competitiveness of agricultural enterprises and the industry as a whole.

\section{Acknowledgments}

The paper is an outcome of the project APVV 0230-07 REDIPE: Regional dimensions of knowledge economy.

\section{References}

BLAAS, G. et al. 1999. Analýza vývoja polnohospodárstva a potravinárstva za obdobie rokov 1990 - 1998: research report. Bratislava : Výskumný ústav ekonomiky polnohospodárstva a potravinárstva. pp. 184.

BLAŽÍK, T. - FALŤAN, V. - TARASOVIČOVÁ, Z. - SAKSA, M. 2011. Land Use Changes in Chosen Districts of Various Productive Agricultural Regions in Context of Transformation Precess. In Geografický časopis/Geographical Journal, vol. 63, 2011. no. 4, pp. 301-323.

BANDLEROVÁ, A. 2005. Situation of the Agricultural Cooperatives in Slovakia, Slovak University of Agriculture in Nitra, 2005, [cit. 2014-03-14]: Retrieved from: http://www.slpk. sk/eldo/aktualne otazky legislativy/bandlerova.pdf

BRUNORI, G. - RAND, S. - PROOST, J. - BARJOLEE, D. GRANBERG, L., - DOCKES, A. 2011. Ch. Towards Conceptual Framework for Agricultural and Rural Innovation Policies, 2011 WP1 - Review of Conceptual Frameworks an Theoretical
Underpinnings, [cit. 2010-06-11]. Retrived from: www. insightproject.net/files/Rapport_insight_WP1final.pdf

BUČEK, M. - REHÁK, Š. - HUDEC, O. 2010. Výskum znalostí a poznatkov $v$ ekonomike - koncepcie, metodológia, výsledky. In Zborník príspevkov z konferencie: Národná a regionálna ekonomika VIII, Herl'any. Košice :Technical University Košice, pp. 105-118. ISBN 978-80-553-0517-2.

BURT, R. S. 2004. Structural Holes vs Networks Closure as Social Capital. In: American Journal of Sociology, vol. 110, 2004. no. 2, pp. 349-399. ISSN 0002-9602.

FÁZIKOVÁ, M. - MARIŠ, M. 2010. Znalostná ekonomika a pol'nohospodárstvo v Nitrianskom kraji. In Zborník príspevkov z konferencie: Národná a regionálna ekonomika VIII, Herlany. Košice : Technical University Košice. pp. 235-245. ISBN 978-80-553-0517-2.

FÁZIKOVÁ, M. et al. 2011. Dimenzie znalostnej ekonomiky v Nitrianskom kraji. Nitra : Slovak University of Agriculture in Nitra. ISBN 978-80-552-0650-9.

GODIN, B. 2005. The linear model of innovation: historical construction of analytical framework. Project of history and sociology of S\&T statistics. Working paper No 30. [Retrieved 2010-07-14]. Retrieved from: http://wwwcsiic.ca/PDF/ Godin_30.pdf

GOODMAN, D. 2003. The Quality Turn and Alternative Food Practices: Reflection and Agenda. In Journal of Rural Studies, vol. 19, 2003, no.1, pp.1-7. ISSN 0743-0167.

HOFFMANN, L. B. 2001. Agricultural Functions and Biodiversity, Tilburg: ECNC-European Centre for Nature Conservation. ISBN 90-76762-10-4.

HUDEC, O. - URBANČíKOVÁ, N. - DŽUPKA, P. - ŠEBOVÁ, M. KLIMOVSKÝ, D. - SUHANYI, L. - ŽELINSKÝ, T. 2009. Podoby regionálneho a miestneho rozvoja. Košice : TU Košice. pp. 245265. ISBN 978-80-553-0117-4.

IVANIČKOVÁ, A. - VLČKOVÁ, V. 2010. L’udský kapitál - implikácie pre znalostnú ekonomiku. In: Zborník príspevkov z vedeckej konferencie: Regionálne dimenzie znalostnej ekonomiky, Herlany. Košice : Technical University Košice. pp. 7-23. ISBN 978-80-225-3095-8.

JARÁBKOVÁ, J. 2003. Analýza ekonomickej štruktúry vidieckeho priestoru na Slovensku. In Podniky v podmínkách procesu globalizace a integrace : Sborník příspěvků z mezinárodní vědecké konference, Ostrava 24.-25. dubna 2003. Ostrava : Technická univerzita, pp. 74-78. ISBN 80-248-0498-0.

KNICKEL, K. - TISENKOPFS, T. - PETER, S. 2009. Innovation processes in agriculture and rural development, Results of a cross-national analysis of the situation in seven countries, research gaps and recommendations. [cit: 2014-05-10], Retrieved from: http://www.insightproject.net/files/IN-SIGHT_ final_report.pdf

KONCOŠ, P. 2005. The development of employment in agricultute in years 1990 - 2005 connected with labour productivity, 2006, [cit. 2014-03-14]: Retrieved from: http:// bandlerova.weby.uniag.sk/files/rackova/PDF/Koncos.pdf

McMICHAEL, P. 2004. Global development and the corporate food regime. In XI World Congress of Rural Sociology. Trondheim. [Retrieved 2010-07-14]. Retrieved from: http:// www.corporate-accountability.org/eng/dicuments/2004/ corporate_food_regime.pdf

PIMBERT, M. P. - THOMPSON, J. - VORLEY, W. T. - FOX, T. KANJI, N. - TACOLI, C. 2001. Global Restructuring, Agri-Food Systems and Livehoods. London: IIED. [Retrieved: 2010- 
07-14]. Retrieved from: http://www.iied.org/pubs/display. php?o=9166|lED\& $n=9 \& \mid=15 \& t=$ food

PLOEG VAN DER, J. D. - RENTING, H. - BRUNORI, G. - KNICKEL, K. - MANNION, J. - MARSDEN, T. - DE ROEST, K. - SEVILLAGUZMAN, E. - VENTURA, F. 2000. Rural development: from practices and policies towards theory. In: Sociologia Ruralis, vol. 40, 2000, no. 4. pp. 391-408. ISSN 1467-9523.

PORTES, A. 1998. Social capital: its Origins and Applications in Modern Sociology. In Annual Review of Sociology, vol. 24, pp.1-24. [cit. 2014-02-12] Retrieved from: doi:10.1146/annurev. soc.30.020404.104342

REHÁK, Š. 2004. Poznatkovo založený regionálny rozvoj: doctoral dissertation thesis. Bratislava : Ekonomická univerzita v Bratislave.

SCOONES, I. - THOPSON, J. 2009. Farmer first revised: innovation for agricultural research and development, Burton on Dunsmore/UK> Practical Action Publishing

TRIGILIA, C. 2001. Social Capital and Local Development. In European Journal of Social Theory, vol. 4, 2001, no. 4, pp. 427442. ISSN 1368-4310.

WAARTS, Y. 2005. Indicators for the quantification of multifunctionality impacts, European Centre for Nature Conservation (ECNC), The Netherlands, 2005, [cit. 2014-03-14]: Retrieved from: http://www.ecnc.org/uploads/documents/ mea-scope-vol.pdf
WILSON, G - RIGG, J. 2003. Post-productivist'agricultural regimes and the South: discordant concepts?. In Progress in Human Geography, vol. 27, 2003, no. 6, pp. 681-707. ISSN 0309-1325.

ZANDER, P. - KARPINSKI, I. - MEIJER, B. J. M. - MICHEL, B. ROSSING, W. A. H. - GROOT, J.C. J. - JOSIEN, E. - RAMBONILAZA, T. - MADUREIRA, L. 2005. Knowledge, Models, Techniques and Tools That Help to Explain and Forecast Multifunctionality of Agriculture: comparative report. [cit. 2010-07-14]. Retrieved from: http://www.wageningenur.nl/en/Publication-details. htm?publicationld=publication-way-333434333539

ZÁVEREČNÁ SPRÁVA strednodobého (mid-term) hodnotenia PRV SR 2007 - 2013, [cit. 2010-07-14]: Retrieved from: http:// www.mpsr.sk/sk/?navlD=32\&navID2=32\&sID=43\&id $=4283$

\section{Contact address:}

doc. Ing. Mária Fáziková, CSc., Slovak University of Agriculture in Nitra, Faculty of European Studies and Regional Development, Department of Regional and Rural Development, e-mail: maria.fazikova@uniag.sk 